\title{
Diethyl Ether Production as a Substitute for Gasoline
}

\author{
Riza Alviany ${ }^{1}$, Arifuddin Wahyudi ${ }^{1}$, Ignatius Gunardi ${ }^{1}$, Achmad Roesyadi $^{1 *}$, Firman Kurniawansyah ${ }^{1}$, Danawati Hari \\ Prajitno $^{2}$
}

${ }^{1}$ Chemical Engineering Department, Industrial Technology Faculty, Sepuluh Nopember Institute of Technology (ITS), Surabaya 60111, Indonesia

${ }^{2}$ Chemical Engineering Industry Departement, Vocation Faculty, Sepuluh Nopember Institute of Technology (ITS), Surabaya 60111, Indonesia

\begin{abstract}
Diethyl ether is one of alternative fuel that could be used as a significant component of a blend or as a complete replacement for transportation fuel. The aim of this research is to produce diethyl ether through dehydration reaction of ethanol with fixed bed reactor using nanocrystalline $\gamma-\mathrm{Al}_{2} \mathrm{O}_{3}$ catalyst. Nanocrystalline $\gamma-\mathrm{Al}_{2} \mathrm{O}_{3}$ catalyst was synthesized by precipitation method using $\mathrm{Al}\left(\mathrm{NO}_{3}\right)_{3} .9 \mathrm{H}_{2} \mathrm{O}$ as precursors and $\mathrm{NH}_{4} \mathrm{OH}$ as the precipitating agent. Dehydration reaction was performed at temperature range of 125 to $225^{\circ} \mathrm{C}$. The result shows that synthesized $\gamma-\mathrm{Al}_{2} \mathrm{O}_{3}$ catalyst gave higher ethanol conversion and diethyl ether yield than that of commercial $\mathrm{Al}_{2} \mathrm{O}_{3}$ catalyst. The use of synthesized $\gamma-\mathrm{Al}_{2} \mathrm{O}_{3}$ catalyst could reach ethanol conversion as high as $94.71 \%$ and diethyl ether yield as high as $11,29 \%$.
\end{abstract}

\section{Introduction}

Diethyl ether (DEE) is an important chemical for the laboratory and industry uses. It has been widely used as a solvent or extractant, reaction medium, fragrance, explosive materials, pharmaceutical chemical processes, fuels and fuel additives [1]-[6]. As a fuel, DEE has been used as starting fluid in countries with cold climates because of its high volatility and low flash point [6]. In addition, cetane and octane number, reasonable energy, high oxygen content, and high miscibility in diesel fuel and bioethanol become DEE available advantage as blending material to improve the ignition [3]. DEE has a potential as an alternative transportation fuel to replace an excessive use of fossil fuels as major energy sources.

The volumetric heating value and octane number are very important parameters for an alternative fuel of gasoline. The latent heat of ethanol is about 3.7 times higher than that of gasoline, which causes lower temperatures during combustion in the engine. A decrease in engine temperature also causes a formation of less amount of NOx. Ethanol with an octane number of 113 and low Reid vapor pressure is considered as an excellent alternative to gasoline but it also causes some problems in cold-start of the engine. Fuel regulations mandate that motor vehicle fuels should have sufficient vapor pressure to cold-start, as low as $-30{ }^{\circ} \mathrm{C}$ [5]. Combustion of alcohols and ethers produce much less unburned hydrocarbons and $\mathrm{CO}$ and $\mathrm{CO}_{2}$ than conventional gasoline [3], [5], [6]. Consequently, ethanol-DEE mixtures are considered as excellent gasoline alternatives which diethyl ether can be produced by dehydration of ethanol over acidic catalysts.

Diethyl ether is generally prepared by the dehydration process of ethanol (Barbet process) using sulfuric acid catalyst (homogeneous catalyst). The downside of this process is the difficulty of catalyst separation and catalyst corrosiveness. Corrosive catalysts make investments in equipment quite expensive. Thus, homogeneous catalysts are replaced by heterogeneous catalysts. heterogeneous catalyst that has long been known for ethanol dehydration is $\mathrm{Al}_{2} \mathrm{O}_{3}$. One of the phase types of $\mathrm{Al}_{2} \mathrm{O}_{3}$ is $\gamma-\mathrm{Al}_{2} \mathrm{O}_{3} \cdot \gamma-\mathrm{Al}_{2} \mathrm{O}_{3}$ which is widely used as catalysts and catalyst supports. $\gamma$-Al2O 3 has been known for having a large surface area with acidic and alkaline active sides. The active sides have resulted from the release of water molecules [7]. Primary alcohol dehydration reaction catalysis by using $\gamma-\mathrm{Al}_{2} \mathrm{O}_{3}$ catalyst can produce ether compounds and alkenes. While the reaction of the secondary alcohol with an acid catalyst can produce alkenes and base catalyst produces ketones through dehydrogenation reaction [8]. To maximize the effectiveness of the catalyst, a study was carried out by varying technology of catalyst manufacturing.

Because of an excessive use of fossils fuel, it is important to produce desirable, higher value chemicals and fuels from clean, cheap, abundantly available feed to

Corresponding author: aroesyadi@yahoo.com 
contribute to the solution of the two major problems of the next century, namely global warming and depletion of oil reserve.

This research was carried out the synthesis of nanocrystalline $\gamma$-alumina from $\mathrm{Al}\left(\mathrm{NO}_{3}\right)_{3} \cdot 9 \mathrm{H}_{2} \mathrm{O}$ by precipitation method. Then, to test the activity of prepared $\gamma-\mathrm{Al}_{2} \mathrm{O}_{3}$, it was applied in $96 \%$ ethanol dehydration reaction into diethyl ether and compared its activity with $\gamma-\mathrm{Al}_{2} \mathrm{O}_{3}$ commercial catalyst.

\section{Experimental}

Some of the steps being taken in this study were $\gamma-\mathrm{Al}_{2} \mathrm{O}_{3}$ catalyst synthesis by precipitation method, $\gamma-\mathrm{Al}_{2} \mathrm{O}_{3}$ catalyst characterization, and DEE production.

\subsection{Materials}

The commercial $\mathrm{Al}_{2} \mathrm{O}_{3}$ used in this study was purchased from Merck Company. Aluminium nitrate nonahydrate (Merck), ammonium hydroxide (Sigma-Aldrich Co. LLC), distilled water (Sumber Ilmiah Persada), hydrochloric acid (37\% from Sigma-Aldrich Co. LLC), molecular sieve, nitrogen gas (PT. Aneka Gas Industri) were also employed.

\subsection{Catalyst Preparation}

Synthesis of $\gamma-\mathrm{Al}_{2} \mathrm{O}_{3}$ was performed by precipitation method. Firstly, aluminum nitrate nonahydrate with different concentration $(0.2,0.3,0.4,0.5$, and $1 \mathrm{M})$ was dissolved in a solution of $\mathrm{HCl}(0.5 \mathrm{M})$ and distilled water. Subsequently, the precipitation was carried out by adding ammonium nitrate to the solution by stirring at several temperatures $\left(60,70,80,90,100^{\circ} \mathrm{C}\right)$ by careful $\mathrm{pH}$ adjustment to 9 . The precipitate was stirred for different time $(3,4,5$, and 6 hours) and was maintained at the same temperature just like in precipitation step. Then, precipitate filtered and washed by distilled water and ethanol and then dried at $75^{\circ} \mathrm{C}$ for 24 hours. The solid precipitate was calcined at $600^{\circ} \mathrm{C}$ under air flow for 6 hours to obtain the synthesized $\gamma-\mathrm{Al}_{2} \mathrm{O}_{3}$ catalyst.

\subsection{Catalyst Characterization}

The synthesized $\gamma-\mathrm{Al}_{2} \mathrm{O}_{3}$ catalyst were characterized using X-ray diffraction (XRD) at Material and Metallurgy Engineering Departement, Sepuluh Nopember Institute of Technology (ITS) to determine the crystallinity and the crystal size of the catalyst. Size of the crystal was calculated by using Scherrer formula based on the data of XRD analysis:

$$
D=\kappa \lambda / \beta \cos \theta
$$

Where $\mathrm{D}$ is the diameter of the crystal, $\kappa$ is the shape factor with a value of $0.9-1.4$ (generally used $\sim 0.9$ ), $\lambda$ is the wavelength of X-ray $(0.15406 \mathrm{~nm}), \theta$ is the diffraction angle (radians), and $\beta$ is the FWHM (Full Width Half Maximum) of the diffraction peak at half maximum intensity (radians).
The surface area, pore size distribution and pore volume were determined using a nitrogen adsorptiondesorption method at Chemical Engineering Departement, Sepuluh Nopember Institute of Technology (ITS).

\subsection{DEE production}

DEE production process was performed by adsorption process in adsorption column and followed by dehydration of ethanol in a reactor. The dehydration of ethanol was carried out in a fixed-bed microreactor with an inside diameter of $0.5 \mathrm{in}$. and length of $30 \mathrm{~cm}$. In the experiment, 10 gram of molecular sieve was loaded into the adsorption column and 3 gram of catalyst was loaded into the reactor. The liquid ethanol was vaporized in a flowing of nitrogen at a flow rate $200 \mathrm{ml} / \mathrm{min}$. the reaction was carried out at several temperatures (125, $150,175,200,225^{\circ} \mathrm{C}$ ). The products condensed by a condenser were analyzed by HP 6890 gas chromatograph with FID using crosslinked methyl siloxane column. Helium (22.98 psi) was used as carrier gas in $\mathrm{GC}$ using the temperature detector at $250^{\circ} \mathrm{C}$. The arrangement of equipment used for DEE production is shown in Fig. 1 below.

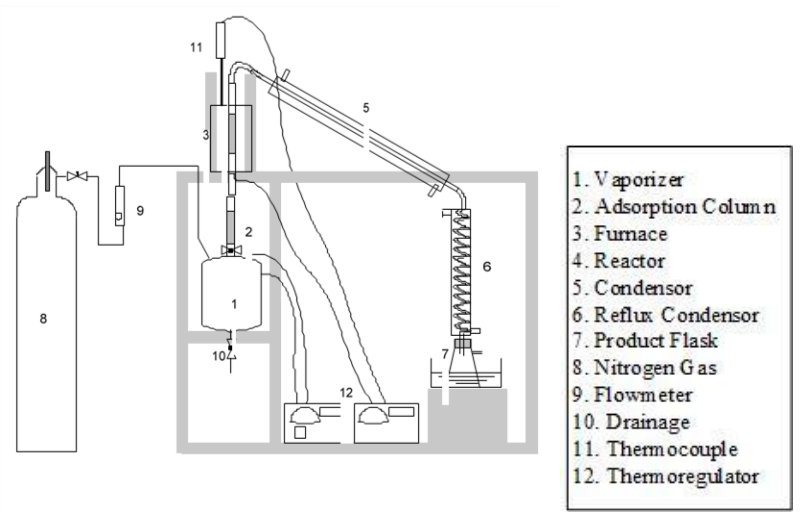

Fig. 1. DEE production equipment

\section{Result and discussion}

\subsection{Nano-crystallite $\mathrm{Al}_{2} \mathrm{O}_{3}$ preparation}

The synthesis/preparation of $\gamma-\mathrm{Al}_{2} \mathrm{O}_{3}$ was performed using precipitation method in which aluminum nitrate nonahydrate $\left(\mathrm{Al}\left(\mathrm{NO}_{3}\right)_{3} \cdot 9 \mathrm{H}_{2} \mathrm{O}\right)$ was used as an aluminum precursor, hydrochloric acid $(\mathrm{HCl})$ and distilled water as a solvent, and ammonium hydroxide $\left(\mathrm{NH}_{4} \mathrm{OH}\right)$ as a precipitating agent. In this research, a variation of the type of solvent used, the concentration of precursor solution, stirring time and temperature of the solution during the precipitation process, has been studied.

For the synthesis process of $\gamma-\mathrm{Al}_{2} \mathrm{O}_{3}$ includes several stages, these are [9]:

First stage

The formation of aluminum hydroxide occurs when $\mathrm{NH}_{4} \mathrm{OH}$ added into the aluminum precursor solution. Equations 2 and 3 are used for reactions using $\mathrm{HCl}$ 
solvents, whereas reaction 4 is used for reactions using distilled water solvent. This stage is illustrated by the reaction as follows:

$$
\begin{gathered}
\mathrm{Al}\left(\mathrm{NO}_{3}\right)_{3}+3 \mathrm{HCl} \rightarrow \mathrm{AlCl}_{3}+3 \mathrm{HNO}_{3} \\
\mathrm{AlCl}_{3}+3 \mathrm{NH}_{4} \mathrm{OH} \rightarrow \mathrm{Al}(\mathrm{OH})_{3} \downarrow+3 \mathrm{NH}_{4} \mathrm{Cl} \\
\mathrm{Al}\left(\mathrm{NO}_{3}\right)_{3}+3 \mathrm{NH}_{4} \mathrm{OH} \rightarrow \mathrm{Al}(\mathrm{OH})_{3} \downarrow+3 \mathrm{NH}_{4} \mathrm{NO}_{3}
\end{gathered}
$$

Second stage

The solution containing precipitate of aluminum hydroxide in the first stage transformed to boehmite crystal precipitate after stirring at a constant temperature (aging with stirring). The reaction is as follows:

$$
\mathrm{Al}(\mathrm{OH})_{3} \rightarrow \mathrm{AlOOH} \downarrow+\mathrm{H}_{2} \mathrm{O}
$$

\section{Third stage}

The precipitate of boehmite crystals from the second stage then washed with water and ethanol sequentially to remove impurities in the form of anions such as nitrate and chloride ions [10]. After that, the boehmite crystal precipitate filtered, dried and then calcined at $600^{\circ} \mathrm{C}$ for 6 hours. The dried precipitate of boehmite crystal is calcined to form $\gamma-\mathrm{Al}_{2} \mathrm{O}_{3}$. The following reactions occur:

$$
2 \mathrm{AlOOH} \rightarrow \mathrm{Al}_{2} \mathrm{O}_{3}+\mathrm{H}_{2} \mathrm{O}
$$

\subsubsection{Effect of solvent in precipitation process}

Two different types of solvents are used to determine the effect of solvent on the diameter of the resulting $\mathrm{Al}_{2} \mathrm{O}_{3}$ crystals. The operation was performed at temperature $80^{\circ} \mathrm{C}$ with 5 hours stirring time.

The results in Fig. 2 show that in all precursor concentration variations, using $0.5 \mathrm{M} \mathrm{HCl}$ solvent produces the smaller size of $\mathrm{Al}_{2} \mathrm{O}_{3}$ crystal than using distilled water solvent. This occurred due to the reaction between $\mathrm{HCl}$ and $\mathrm{NH}_{4} \mathrm{OH}$ will produce $\mathrm{NH}_{4} \mathrm{Cl}$. The presence of $\mathrm{NH}_{4} \mathrm{Cl}$ in the solution would increase the viscosity of the solution, decreasing the molecular mobility and dielectric matrix constant of mother solution. It also increased the distance between particles of aluminum hydroxide thus preventing aggregation of aluminum hydroxide particles during the process of nucleation and growth of particles [10].

Based on Fig. 2, it can be seen that the crystal size of the resulting $\gamma-\mathrm{Al}_{2} \mathrm{O}_{3}$ is proportional to the amount of precursor used. The lower the concentration of precursor used, the resulting crystal size is also smaller. A lower concentration of precursor make the distance between the particles of aluminum hydroxide higher where can reduce the aggregation of particles of aluminum hydroxide on the stage of nucleation and growth of particles. The size of the smallest crystal produced at 0.2 $\mathrm{M}$ concentration of precursor and $0.5 \mathrm{M} \mathrm{HCl}$ solvent. The crystal diameter is $8.62248 \mathrm{~nm}$, while the size of the largest crystals produced at $1 \mathrm{M}$ concentration of precursor with distilled water solvent which has diameter $23.6881 \mathrm{~nm}$

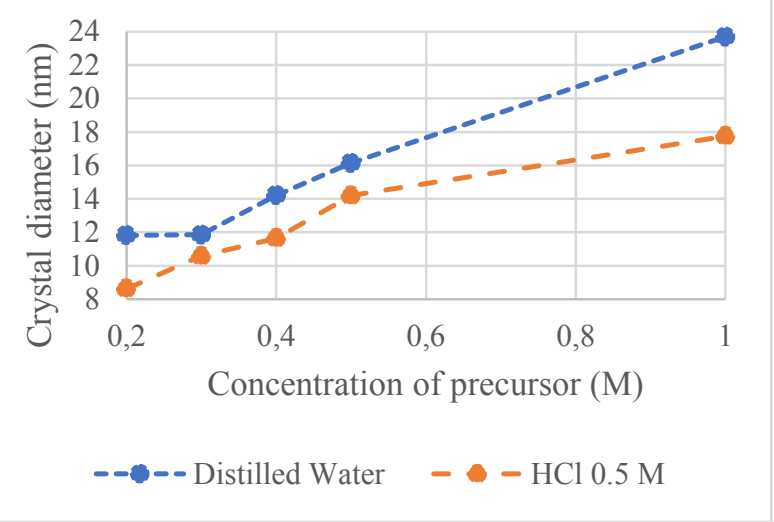

Fig. 2. Crystal diameter of $\gamma-\mathrm{Al}_{2} \mathrm{O}_{3}$ at different solvent type and precursor concentration

\subsubsection{Effect of stirring time in precipitation process}

The operation was performed at the varied stirring time $(3,4,5,6$ hours) while the concentration of precursor and precipitation temperature was kept constant at $1 \mathrm{M}$ and $80^{\circ} \mathrm{C}$ respectively. The solvent used was $0.5 \mathrm{M} \mathrm{HCl}$.

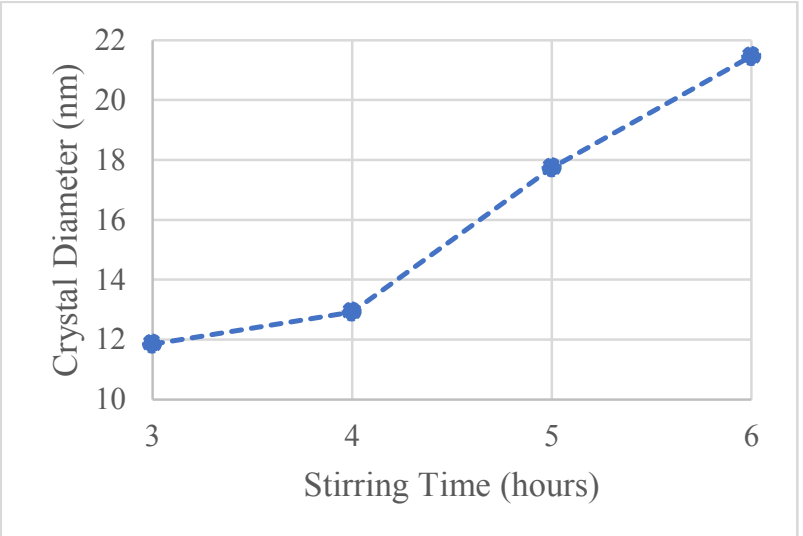

Fig. 3. Crystal diameter of $\gamma-\mathrm{Al}_{2} \mathrm{O}_{3}$ at different stirring time

In Fig. 3 it has been shown that the stirring time on precipitation processes influence a crystal diameter of $\gamma$ $\mathrm{Al}_{2} \mathrm{O}_{3}$ produced significantly. The longer the stirring time, the greater the diameter of the resulting crystals. This happens because of the longer the stirring time the mobility of particles in the solution lasts longer Longer duration of stirring time cause particle mobility and collision intensity between the particles in solution increased, so aggregation that occurs will be greater and cause a growth of the crystal particle size of $\gamma-\mathrm{Al}_{2} \mathrm{O}_{3}$ greater. The smallest particle size is produced by stirring for 3 hours which is $11.85287 \mathrm{~nm}$.

\subsubsection{Effect of temperature in precipitation process}

The operation was performed at several operating temperatures $\left(60,70,80,90,100^{\circ} \mathrm{C}\right)$ while the concentration of precursor and stirring time was kept constant at $1 \mathrm{M}$ and 3 hours respectively. The solvent used was $0.5 \mathrm{M} \mathrm{HCl}$. 


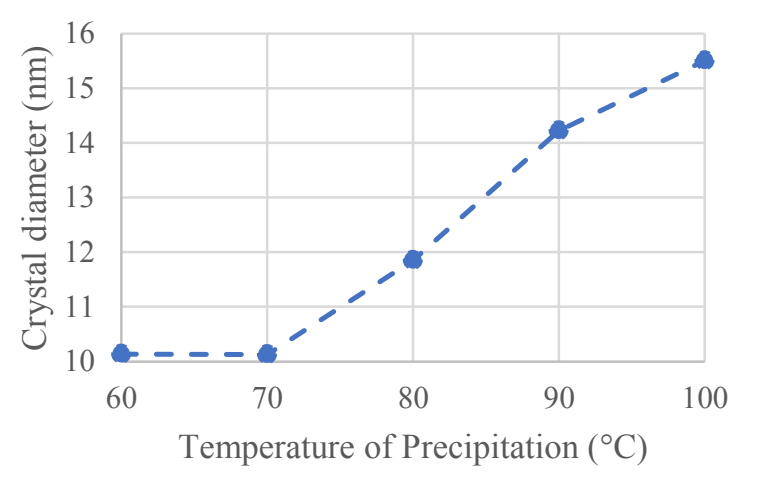

Fig. 4. Crystal diameter of $\gamma-\mathrm{Al}_{2} \mathrm{O}_{3}$ at different precipitation temperature

Fig. 4 shows precipitation temperature is a parameter that influences the size of crystals $\gamma-\mathrm{Al}_{2} \mathrm{O}_{3}$. Generally, the size of $\gamma-\mathrm{Al}_{2} \mathrm{O}_{3}$ crystals produced increases with the rising temperature of the precipitation process. An increasing temperature at precipitation process decrease the viscosity of the solution and increase the particle movement so at higher temperature the aggregation of the particle bigger. The optimum condition was $70^{\circ} \mathrm{C}$ which produce the smallest crystal size, i.e. 10.12907 nm.

\subsection{Catalyst characterization for catalytic test}

For the catalytic test, the catalyst which used was the catalyst that prepared using $1 \mathrm{M}$ precursor concentration and $0.5 \mathrm{M} \mathrm{HCl}$ as a solvent stirred for 3 hours at $70^{\circ} \mathrm{C}$ (PR-C) while commercial $\gamma-\mathrm{Al}_{2} \mathrm{O}_{3}$ catalyst as a comparison. Those variables are the optimum variable which produce high yield of $\gamma-\mathrm{Al}_{2} \mathrm{O}_{3}$ and $\gamma-\mathrm{Al}_{2} \mathrm{O}_{3}$ crystal size is still in a nano size.

\subsubsection{Phase analysis}

The XRD patterns of the synthesized and commercial $\gamma$ $\mathrm{Al}_{2} \mathrm{O}_{3}$ are shown in Fig. 5. In that figure, both of catalyst has three peaks at $2 \theta=38^{\circ}, 2 \theta=45.7^{\circ}$ and $2 \theta=66.7^{\circ}$, this pattern is suitable with the data (JCPDS) Joint Committee on Powder Diffraction Standards in Fig. 6.

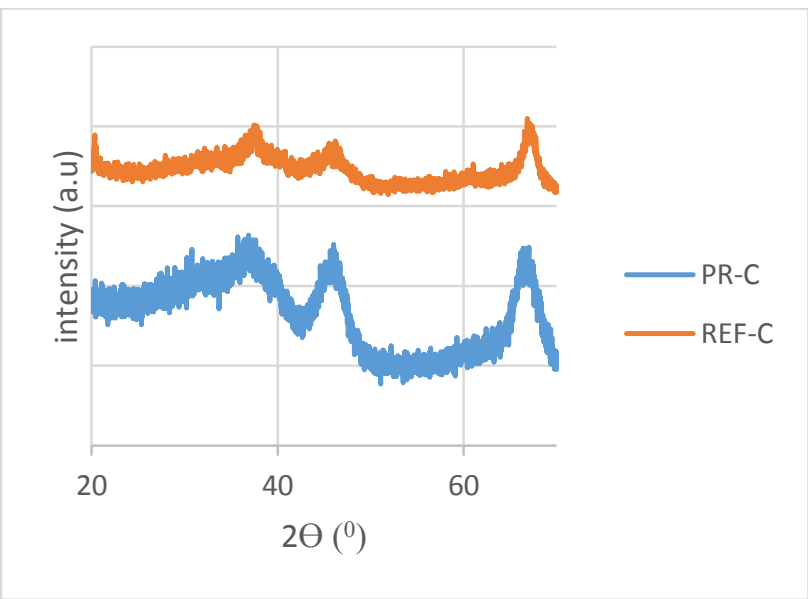

Fig. 5. XRD patterns of synthesized (PR-C) and commercial $\gamma$ $\mathrm{Al}_{2} \mathrm{O}_{3}$ (REF-C)

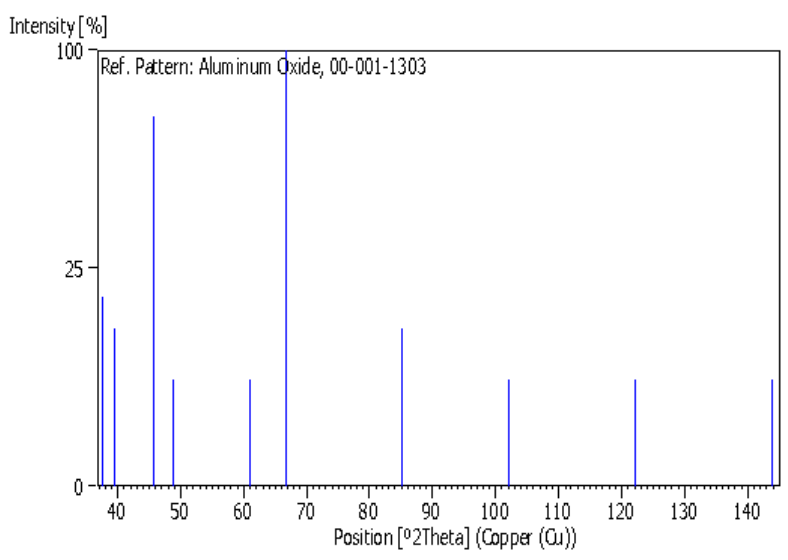

Fig. 6. XRD patterns of $\gamma-\mathrm{Al}_{2} \mathrm{O}_{3}$ from JCPDS

The crystallite sizes were calculated using Scherrer formula. Results of calculation are listed in Table 1.

Table 1. Crystallite sizes of the catalyst

\begin{tabular}{|c|c|}
\hline & $\mathrm{D}(\mathrm{nm})$ \\
\hline PR-C & 10.1183 \\
\hline REF-C & 80.3913 \\
\hline
\end{tabular}

\subsection{2 $\mathrm{N}_{2}$ adsorption-desorption (BET) analysis}

Physical properties of catalyst (specific surface area, total pore volume, and average pore diameter) are presented in Table 2.

Table 2. Physical properties of the catalyst

\begin{tabular}{|c|c|c|c|}
\hline Catalyst & $\begin{array}{c}\text { Specific Surface } \\
\text { Area }\left(\mathrm{m}^{2} / \mathrm{g}\right)\end{array}$ & $\begin{array}{c}\text { Pore } \\
\text { Diameter } \\
(\mathrm{nm})\end{array}$ & $\begin{array}{c}\text { Pore } \\
\text { Volume } \\
(\mathrm{cc} / \mathrm{g})\end{array}$ \\
\hline PR-C & 241.437 & 3.839 & 0.241 \\
\hline REF-C & 133.420 & 6.185 & 0.253 \\
\hline
\end{tabular}

The result shows that synthesized $\gamma-\mathrm{Al}_{2} \mathrm{O}_{3}$ (PR-C) have a higher specific surface area and smaller pore diameter than commercial catalyst $\gamma-\mathrm{Al}_{2} \mathrm{O}_{3}$ (REF-C) which may decrease higher hydrocarbon and byproducts leading to increasing of main product selectivity and ethanol conversion. In addition, the high surface area would affect to the increased catalytic activity of ethanol dehydration [11].

Result at Table 1 and Table 2 show a correlation with an assumption that solids in the form of particles, so the surface area for a solid with a certain mass is greater if the particle size is smaller. By defining the specific surface area as the ratio of the total area of the solid surface to the mass, the specific surface area is greater if the particle size is smaller.

\subsection{DEE process production}


Diethyl ether production process in this research combining two steps, they are adsorption process and the previous process. For this purpose, it will be compared the activity of $\gamma-\mathrm{Al}_{2} \mathrm{O}_{3}$ catalyst which prepared by precipitation method (PR-C) with $\gamma-\mathrm{Al}_{2} \mathrm{O}_{3}$ commercial catalysts (REF-C).

Adsorption process aimed to reduce the water content in the ethanol feed. To determine the achievement of the adsorption process, an analysis of the ethanol feed before entering the adsorption column and the output product of adsorption column was done. Ethanol was detected at a retention time of 3.27 minutes and water was detected at a retention time of 3.82 minutes. Based on the results of the GC analysis, there is increasing of ethanol concentration from $95.3 \%$ (before entering the adsorption column) to $97.77 \%$ (after passing through the adsorption column). An increase in ethanol concentration is happened because of some water in the ethanol solution are adsorbed by molecular sieve. Basically, a molecular sieve adsorbent using in any practice can adsorb sufficient water contained in ethanol [12], [13].

In the ethanol conversion process, the reaction which may occur is a dehydration reaction of ethanol (formation

of diethyl ether compounds, and the formation of ethylene compounds) [4]. Fig. 7 and 8 shows catalytic reactions. The catalytic test aimed to determine the performance of $\gamma-\mathrm{Al}_{2} \mathrm{O}_{3}$ catalyst that was prepared in chromatographic analysis of the liquid product reaction at a temperature of $175^{\circ} \mathrm{C}$ using PR-C catalyst (Fig. 7) and REF-C catalyst (Fig. 8). From chromatogram, diethyl ether and residual ethanol compounds were detected, while the water was not detected in the GC chromatogram. Ethylene compounds might be formed in the gas phase products, but in this research, chromatographic analysis was not performed for gas product. Diethyl ether was detected at a retention time of 6.052 minutes, ethanol was detected at a retention time of 5.3 minutes, and methanol was detected at a retention time of 4.5 minutes. Methanol formation process might exist due to the reaction between methane with water (Eq-7).

$\mathrm{CH}_{4}+\mathrm{H}_{2} \mathrm{O} \leftrightarrows \mathrm{CH}_{3} \mathrm{OH}+\mathrm{H}_{2} \Delta \mathrm{G}_{398.15}=117,437.85 \quad \mathrm{~J}$ (7)

Another process might happen as the effect of catalytic activity of alumina ie cracking, isomerization and dehydration process [14]. The methanol formation might also occur through the reaction:

$\mathrm{CO}+2 \mathrm{H}_{2} \leftrightarrows \mathrm{CH}_{3} \mathrm{OH} \quad \Delta \mathrm{G}_{398.15}=-2,347.41 \quad \mathrm{~J}$ (8)

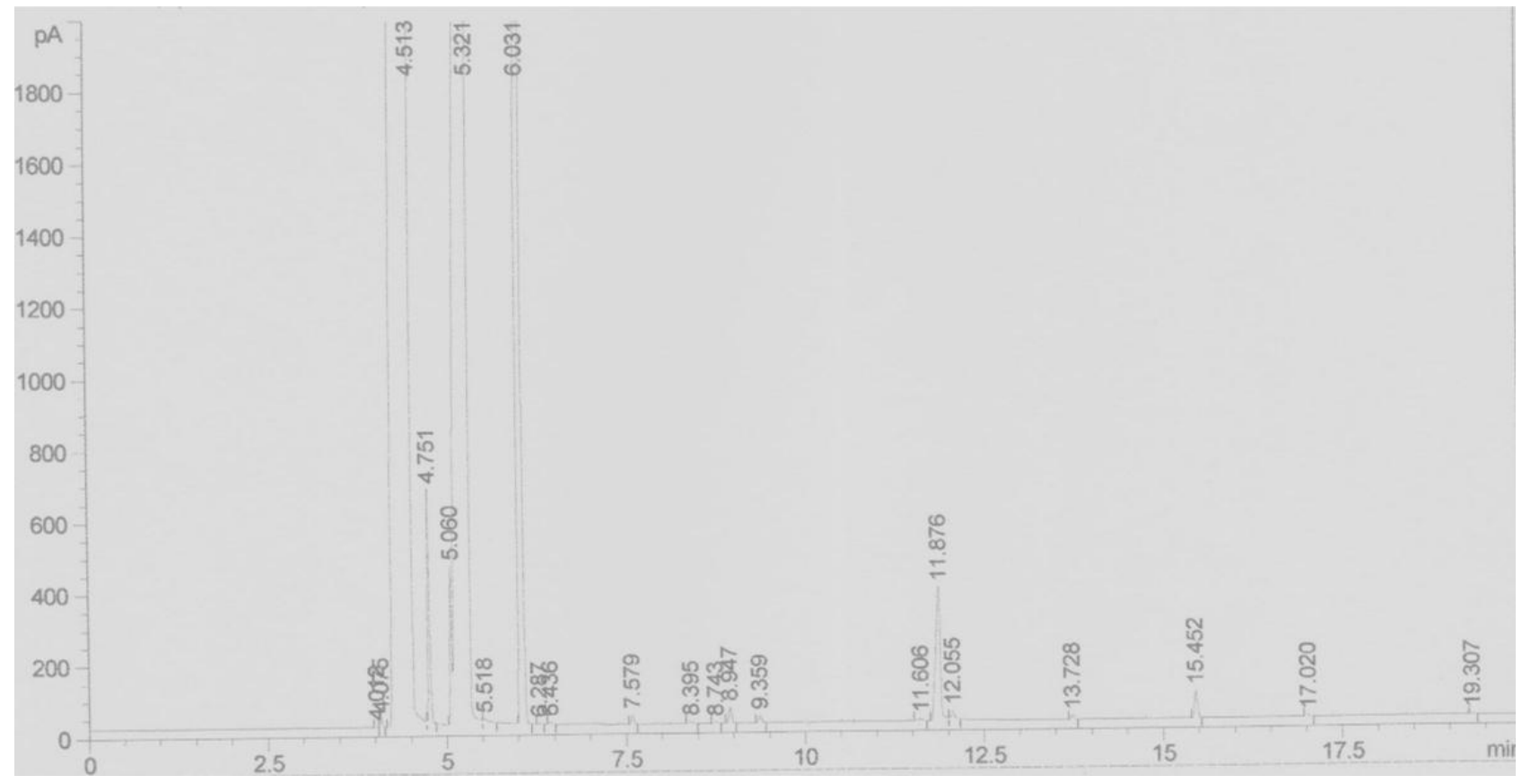

Fig.7. Chromatogram of reaction product using PR-C catalyst at $175^{\circ} \mathrm{C}$ of reaction temperature 


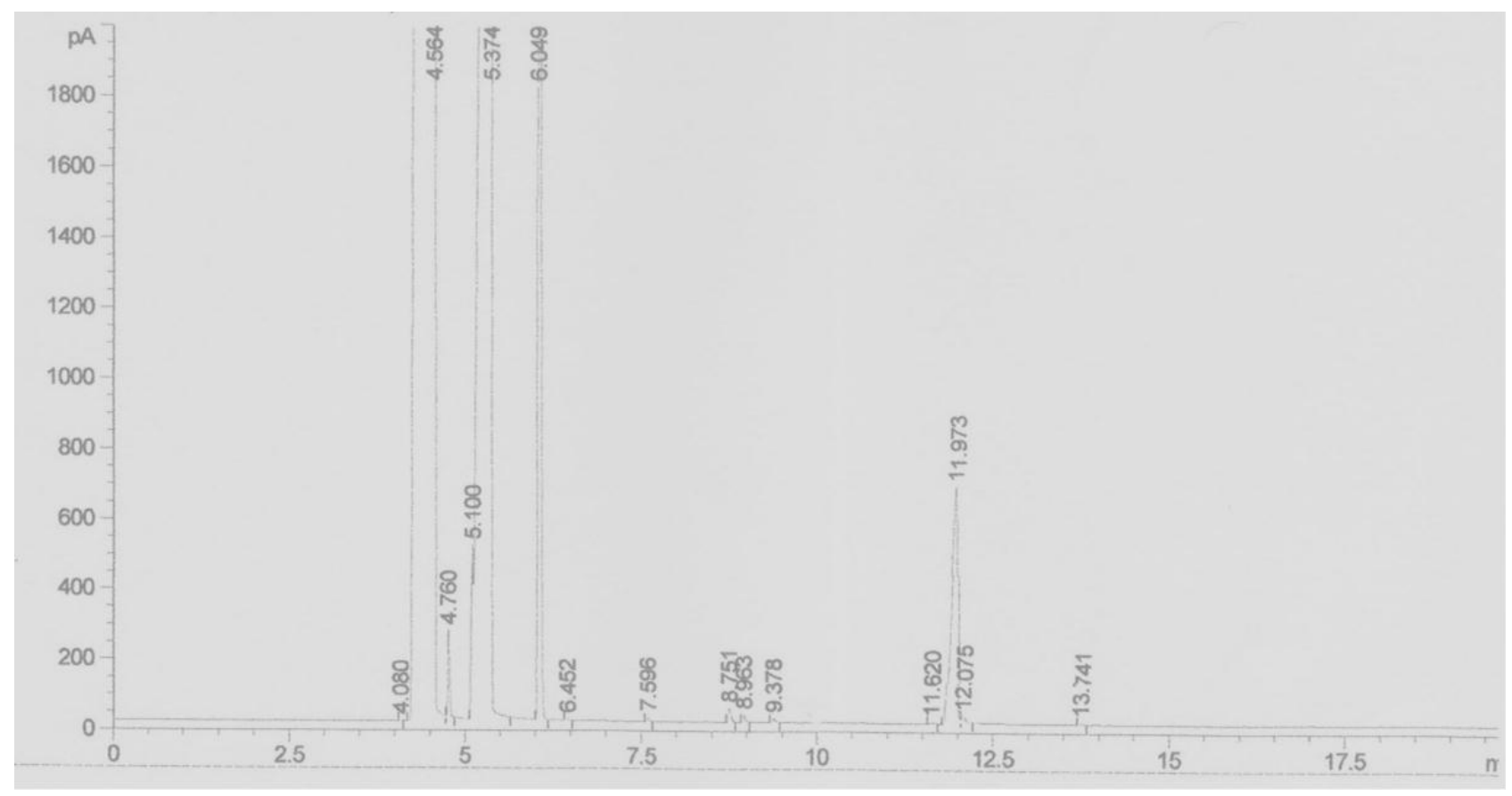

Fig.8. Chromatogram of reaction product using REF-C catalyst at $175^{\circ} \mathrm{C}$ of reaction temperature

Based on thermodynamics concept, the reaction can be predicted using thermodynamic parameters. A chemical reaction can happen if the value of the Gibbs energy change of a reaction at a specific operating temperature is negative $(\Delta$ Greaction $<0)$ [15]. Judging from the value of $\Delta$ Gibbs energy, the possible reaction for the formation of methanol compounds in the present study is reaction (8). It can be seen at the operating conditions (reaction temperature) in this research, the value of the Gibbs energy change in reaction (8) is negative $\left(\Delta \mathrm{G}_{398.15}<0\right)$, while the reaction (7) has positive Gibbs energy change $\left(\Delta \mathrm{G}_{398.15}>0\right)$.

To know the effectiveness of catalyst, calculation of diethyl ether yield and ethanol conversion are necessary as a reaction parameter.

Fig. 9 shows the result of the conversion of ethanol dehydration reaction at various operating temperatures. From the fig. 9, either with the use of $\gamma-\mathrm{Al}_{2} \mathrm{O}_{3}$ catalyst which was prepared by precipitation method (PR-C) or with $\gamma-\mathrm{Al}_{2} \mathrm{O}_{3}$ commercial catalyst (REF-C) has increasing conversion of ethanol as increasing of the reaction temperature. Increased temperatures can increase the conversion of ethanol according to the Arrhenius equation. In this equation, the increase of temperature will increase the reaction rate constants that will increase the rate of reaction [5].

The uses of PR-C catalysts generally produced ethanol conversion greater than using REF-C catalyst. This happened because it has been known that the PR-C catalyst has higher surface area than the REF-C catalyst. Higher surface area will increase the conversion of ethanol because it can increase the opportunity for the occurrence of reaction (adsorption and conversion process) [14].

In addition to the ethanol conversion, in this research also calculated the diethyl ether yield which produced by the reaction using catalyst PR-C and REF-C. The diethyl ether yield is shown in the following figure.

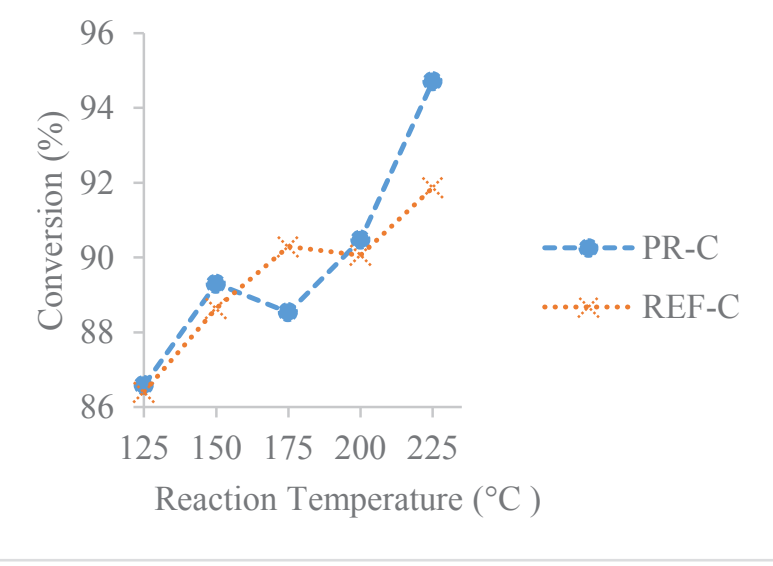

Fig.9. Ethanol coversion vs reaction temperature of ethanol dehydration process using PR-C dan REF-C catalyst

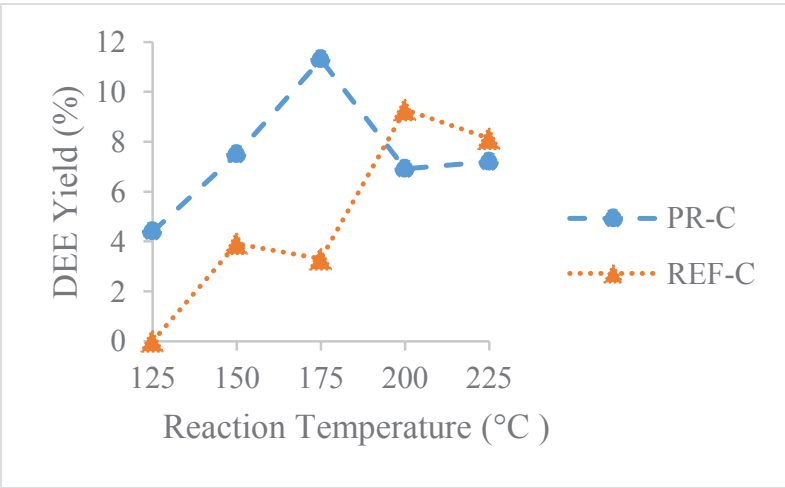

Fig.10. DEE yield vs reaction temperature of ethanol dehydration process using PR-C and REF-C catalyst

From Fig. 10, we can see that using PR-C catalyst has a greater yield of diethyl ether than using REF-C 
catalyst. That happens because PR-C catalyst has a higher surface area than REF-C catalyst. The greatest DEE yield is $11.29 \%$ was produced by using PR-C catalyst while the REF-C catalyst produced DEE yield as $9.28 \%$.

Fig. 10 also shows that the increasing of DEE yield is not linear to the increase of reaction temperature. This suggests that the reaction occurs in the catalytic test is not a single reaction but a multi-reaction where some reactions occur other than diethyl ether formation reaction of ethanol. Other reactions that might occur in the catalytic reaction process is dehydration reaction of ethanol to diethyl ether (Eq-9); dehydration reaction of ethanol to ethylene (Eq-10); reaction of steam reforming (steam reforming) to produce carbon monoxide and hydrogen (Eq-11); and decomposition of ethanol to methane, carbon monoxide and hydrogen (Eq-12) [11].

$$
\begin{aligned}
& 2 \mathrm{C}_{2} \mathrm{H}_{5} \mathrm{OH} \leftrightarrows \mathrm{C}_{2} \mathrm{H}_{5} \mathrm{OC}_{2} \mathrm{H}_{5}+\mathrm{H}_{2} \mathrm{O} \Delta \mathrm{G}_{398.15}=-57,822.3 \mathrm{~J}(9) \\
& \mathrm{C}_{2} \mathrm{H}_{5} \mathrm{OH} \leftrightarrows \mathrm{C}_{2} \mathrm{H}_{4}+\mathrm{H}_{2} \mathrm{O} \Delta \mathrm{G}_{398.15}=-4,363.3 \mathrm{~J} \\
& \mathrm{C}_{2} \mathrm{H}_{5} \mathrm{OH}+\mathrm{H}_{2} \mathrm{O} \leftrightarrows 2 \mathrm{CO}+4 \mathrm{H}_{2} \Delta \mathrm{G}_{398.15}=77,331.5 \mathrm{~J} \\
& \mathrm{C}_{2} \mathrm{H}_{5} \mathrm{OH} \leftrightarrows \mathrm{CH}_{4}+2 \mathrm{CO}+4 \mathrm{H}_{2} \Delta \mathrm{G}_{398.15}=-42,577.7 \mathrm{~J}(12)
\end{aligned}
$$

From some reactions above, theoretically (based on the value $\left.\Delta \mathrm{G}_{\text {reaction }}\right)$ reactions which occured in this catalytic reaction of ethanol is ethanol dehydration reaction (Eq-9 and 10) and the decomposition of ethanol (Eq-12), while the steam reforming reaction (Eq-11) at the operating temperature of this research did not occur which can be seen from the value of the Gibbs energy changing has positive value.

Fig. 10 shows that the yield of diethyl ether decreased at high temperatures. This could happen because the catalytic test process at this research which operated at high temperature can trigger reactions to produce a larger gas product and decreasing the rate of the reaction towards the formation of diethyl ether. This can be explained by analyzing changes in the Gibbs energy of the reactions (Eq-9, Eq-10, and Eq-12) at each reaction temperature. Value of Gibbs energy change for each reaction is shown by the following picture.

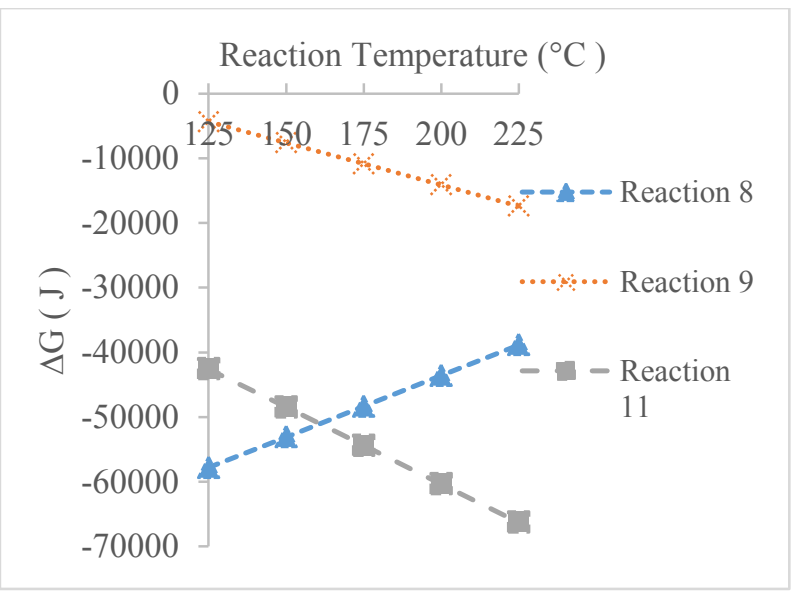

Fig.11. Value of $\Delta \mathrm{G}_{\text {reaction }}$ vs reaction temperature
Fig. 11 shows that the value of the Gibbs energy change $\left(\Delta \mathrm{G}_{\text {reaction }}\right)$ in diethyl ether formation reaction (Eq 9) are more positive (go up) with the increase of reaction temperature. It indicates that the reaction towards the formation of diethyl ether decreases with increasing temperature, due to more minimum (more negative) value of the Gibbs energy change $\left(\Delta \mathrm{G}_{\text {reaction }}\right)$ make the reaction easier take place [15]. Instead of gas-forming reaction (Eq-10 and Eq-12) has the value of Gibbs energy change $\left(\Delta G_{\text {reaction }}\right)$ are more negative (go down) with increasing reaction temperature. This shows that with increasing temperature the reaction rate of the reaction towards the formation of gas will be even greater.

\section{Conclusion}

Based on this research, it may be concluded that: $\gamma$ $\mathrm{Al}_{2} \mathrm{O}_{3}$ nanocrystallite can be produced by using precipitation method with $\mathrm{Al}\left(\mathrm{NO}_{3}\right)_{3} \cdot 9 \mathrm{H}_{2} \mathrm{O}$ as an aluminum precursor, $\mathrm{NH}_{4} \mathrm{OH}$ as precipitating agent and $0.5 \mathrm{M} \mathrm{HCl}$ and distilled water as solvent. Concentration of aluminum precursors, type of solvent, time of stirring, temperature of precipitation process influences the size of $\gamma-\mathrm{Al}_{2} \mathrm{O}_{3}$ crystal produced. Generally, the catalyst which prepared by precipitation method (PR-C) have a greater ethanol conversion and DEE yield than $\gamma$-A12O3 commercial catalysts because of its high surface area. The biggest conversion reaction is resulted by using PR$\mathrm{C}$ catalyst at $225^{\circ} \mathrm{C}$ of reaction temperature as $94.8216 \%$. The biggest DEE yield is resulted by using PR-C catalyst $175^{\circ} \mathrm{C}$ of reaction temperature as $11.04 \%$.

The authors would like to thank Ministry of Research Technology and Direktorat Riset dan Pengabdian Masyarakat Direktorat Jenderal Penguatan Riset dan Pengembangan Kementerian Riset, Teknologi, dan Pendidikan Tinggi Republik Indonesia for financial support under grant PTUPT Scheme for the year of 2017 granted through Institute for Research and Community Services Sepuluh Nopember Institute of Technology.

\section{References}

1. M. Sakuth et al., Ullmann's Encyclopedia of Industrial Chemistry (Wiley-VCH Verlag GmbH \& Co. KGaA,Weinheim, 2010)

2. T. K. Phung and G. Busca, Chem. Eng. J. 272, 92101 (2015)

3. A. Ibrahim, Appl. Therm. Eng. 107, 853-862 (2016)

4. T. Kito-Borsa, D. a. Pacas, S. Selim, and S. W. Cowley, Ind. Eng. Chem. Res. 37, 97 (1998)

5. T. Doğu and D. Varișli, Turkish Journal of Chemistry 31, 5 (2007)

6. B. Bailey, J. Eberhardt, S. Goguen, and J. Erwin, SAE transactions, 972-978 (1997)

7. W. Wibowo, S. Sunardi, and I. Yulia, Bull. Chem. React. Eng. Catal. 2, 21 (2007)

8. B. C. Shi and B. H. Davis, Journal of Catalysis157, 2 (1995) 
9. O. Rahmanpour, A. Shariati, M. Reza, and K. Nikou, Int. J. Chem. Eng. Appl. 3, 2 (2012)

10. J. Kong, B. Chao, T. Wang, and Y. Yan, Powder Technol. 229, 7-16 (2012)

11. Y. Chen et al., J. Ind. Eng. Chem. 16, 5 (2010)

12. V. J. Chopade, Y. P. Khandetod, and a G. Mohod, Int. J. Emerg. Technol. Adv. Eng. 5, 11, (2015)

13. M. Simo, Sep. Purif. Technol. Biorefineries, 503512 (2013)

14. H. Scott Fogler, Elements of chemical reaction engineering (Prentice Hall, New Jersey,1987)

15. J. M. Smith, H. C. Van Ness, and M. M. Abbott, Introduction to Chemical Engineering Thermodynamic (McGraw-Hill Education, New York, 2005) 